\title{
Children and youth: A central cause in the circulatory mechanisms of the League of Nations (1919-1939)
}

\author{
Joëlle Droux
}

Published online: 8 February 2015

(C) UNESCO IBE 2015

\begin{abstract}
In recent decades, historical studies of public policies on children and youth have paid scant attention to the transnational dimension which may have governed their emergence. This article focuses on the transnational perspective of social and cultural history, to understand the role that international organizations have played in disseminating child welfare measures. It focuses on the workings of the Child Welfare Committee (CWC) of the League of Nations, and the internal transactions and mechanisms that enabled it to play a central role in defending the cause of children between the world wars. Analysis of the committee's work reveals the dissemination mechanisms in contemporary social policy, and the role played by international governmental and private organizations. The article also describes the emergence of the first international networks devoted to child welfare in the late 1800s, the circumstances around the CWC's creation, and the mechanisms through which the League of Nations became a collegial centre of expertise on both child welfare and its related policies.
\end{abstract}

Keywords International organizations - Child welfare - League of Nations · Child welfare policy

The history of public policies on child welfare has been thoroughly researched. Over the past two centuries, a good many studies have focused on how these policies emerged, considering their educational, social, legal and even cultural components. However, they have not necessarily shed light on the transnational dimension that influenced their emergence. By focusing primarily on their own national contexts of origin, these studies gloss over the contribution that international channels (of ideas, knowledge and models) made to these processes.

J. Droux (两)

University of Geneva, 40 boulevard du Pont d'Arve, Geneva, Switzerland

e-mail: Joelle.droux@unige.ch 
At first, although these comparative studies did not directly focus on these dynamic aspects, they led historians to notice the convergence between various national policies (Cooter 1992; Dupont-Bouchat and Pierre 2001). But the so-called transnational turn led historians to pay more attention to this external source of inspiration for national policy, particularly during the era of the League of Nations (Gorman 2012; Iriye and Saunier 2009; Pedersen 2007). Since then, several authors have focused on the impact that this dynamic of flows and exchanges had on the structure of child and youth policies, and have provided valuable mappings of the networks and organizations that existed between the two wars (Fuchs 2007). But they have not focused on how these agencies operated internally. Opening up the black boxes of their archives, we begin to see their underlying transactions: the very mechanisms that made it possible to develop a new mode of international social governance, and to disseminate the basic knowledge and know-how (Kott and Droux 2013; Marshall 2009).

In this article, I contribute to deepening our knowledge of the globalization process, especially by examining a specialized body of the League of Nations: the Child Welfare Committee (CWC). Created in 1925, the committee took on a central role in international collaborations between movements active in the field of child welfare. It did not begin with a mandate determined by treaty, which makes this examination all the more revealing. Just like other bodies within the League, the CWC had to develop its own rules of operation, and build its legitimacy in relation to states and civil society. Therefore, this analysis of its activities should add to our knowledge about the circulatory mechanisms in the field of contemporary social policy, and thus about the role played by international governmental and private organizations (Hofstetter and Schneuwly 2013; Kott 2008; Saunier 2008).

This article is divided into three sections. I first summarize the emergence of international networks devoted to child welfare before 1919, and then their transformation during the post-war period, a time when this age group was becoming a major focus of attention. I next examine the creation of the CWC, which marked a new era in collaboration between networks. Finally, I concentrate on the relationships between these organizations, showing how they managed to overcome their disagreements to establish a collegial centre of expertise on child welfare policies. I show how they managed to promote new models of intervention focusing on youth, creating a basis for the progressive convergence of Western child-oriented policies between the wars.

\section{The internationalization of child welfare: Hopes and failures, between war and peace (1890-1919)}

The globalization process, which accelerated in the second half of the nineteenth century, resulted in the emergence and development of a great diversity of international associative networks, which progressively adopted permanent structures (Boli and Thomas 1999; Conrad and Sachsenmaier 2012; Laqua 2011). These structures were intended to bring together groups of experts interested in disseminating models of intervention, particularly on social policy issues. The agencies concerned aspired to become important partners of states: as sources of advice and documentation when efforts to develop reform measures required technical expertise, they tried to demonstrate to their state partners the diversity of knowledge and experience accumulated abroad. In addition to serving as platforms for circulating models or ideas internationally, these networks were also able to engage in various forms of lobbying for certain reforms. This was the case of the reformers' network (la nébuleuse réformatrice, or reformist nebula) which assumed the role of an advocacy 
network in the field of social insurance, unemployment and welfare (Gregarek 1995; Keck and Sikkink 1998).

The cause of child welfare was also drawn into this transnational trend, which was pushing associative networks to develop permanent governance structures. At first, this interest in children covered a diversity of fields, and by the end of the $19^{\text {th }}$ century they were clearly compartmentalized: some networks focused on protecting young children, and others on taking action against prostitution, or for endangered or delinquent children (Rollet 2001). In the early $20^{\text {th }}$ century, a federating process began to emerge (Droux 2011). Central to this process was the conviction that children were special beings, requiring global protection of their individuality based on a better knowledge of their needs and capacities, which were then being explored by professionals in pedology (Hofstetter 2012). An organization that could group together these various specialities could serve as a multi-disciplinary platform for expertise. Therefore, in Brussels in 1913, participants at an international congress established an international bureau devoted to the cause of children, and to promoting child-oriented reforms; this congress brought together representatives of associations and governments from over 30 countries. However, they failed to resolve a crucial issue: the practical organization of collaboration between these networks, which had thus far been acting autonomously with differing agendas. This first attempt at internationalization did not have time to take root, as the war prevented its effective implementation, at least in Europe. Elsewhere, and particularly at the pan-American level, this federating movement around the cause of children gave rise more rapidly to a form of crystallization (Birn 2007).

During the war, most efforts around child welfare were focused on national needs (Fisher 2011; Pignot 2012), though several bilateral relief efforts focused on war orphans abroad; for example Great Britain took in Belgian refugee families. When the war ended, childhood and youth became priorities as countries looked not only to reconstruction, but particularly to reconciliation. Indeed, the recovery of international dialogue seemed to depend on the capacity of youth to develop peaceful relations with former enemies, as a delegate to the Assembly of the League of Nations pointed out:

The children of to-day are the citizens, the politicians, the statesmen of the future.

Everything that we can do to strengthen the physical constitution, clarify the mental outlook and improve the moral fibre of the children of to-day will help to ensure the peace of the world when they reach man's estate. (LON 1924, p. 176)

In the aftermath of the conflict, many international networks took on this agenda: for them, children and youth were subjects that required investment at both the national and international levels as a basis for the work of peace through the Western democratic model, as embodied by the League.

Indeed, in the years between 1919 and 1925, the young generations aroused the interest of the League of Red Cross Societies, the International Labour Organization (ILO), the Save the Children International Union, the International Association for the Protection of Children, the Advisory Committee on the Traffic of Women and Children and the International Bureau of Education; these were the principal agencies among the many whose activities focused on children or education for peace in the immediate post-war years.

As these networks emerged in parallel, so did competition between them, since some aimed to become the principal partners of intergovernmental agencies: the League and the ILO (Droux 2012a, 2013a). Two in particular were set on monopolizing the cause of children and federating the cluster of private organizations active in this field, engaging in fierce rivalry to do so. They were the Save the Children International Union (SCIU), 
founded in Geneva and supported by Great Britain and Switzerland; and the International Association for the Protection of Children (IAPC), created in 1921 in Brussels with the support of the Belgian and French authorities. Confrontations were legion between these movements, whose causes and aims were so similar: they competed to take over neighbouring networks, to dominate national committees, to recruit speakers for international congresses, and to determine their respective agendas. The issue that brought these turf wars to the boil was their relations with the League. To be sure, such a rapprochement promised legitimacy. But in contemplating the League, they began to fear some loss of independence, given the League's complex bureaucratic procedures and involvement in sensitive diplomatic tensions (AEG, ASCIU 1923), particularly as its credibility was still fragile. This may explain why networks were still measured in their attraction to the League; for example, international bureaus were less than enthusiastic about claiming formal recognition under the terms of Article 24 of the Charter (ALON [Archives of the League of Nations], section 138B/R 1028). Child-welfare oriented networks did not escape this dilemma.

In practice, the SCIU, which had been regularly associated with the League since 1920 over humanitarian issues, preferred to maintain its independence. Its leaders were represented on ad hoc technical committees of the League, but continued to carry out their own humanitarian actions. For its part, the IAPC in Brussels, a semi-governmental organization gathering together private associations, individual members and government delegates, endeavoured to obtain a so-called detached-attached status with the League, similar to that of the International Institute of Intellectual Cooperation. This status would have allowed the IAPC to keep its headquarters in Brussels, and meanwhile become a technical agency of the League. The Belgian government supported the IAPC request in the council, but Great Britain opposed it, fearing that organizations parallel to the League would proliferate (Marshall 1999). These proposals placed the League's institutions in a particularly delicate situation. Article 24 of the charter entrusted the League with authority over international bureaus, making it responsible for preventing duplication between them (LON 1921). This was precisely the purpose of the Belgian request, which made British opposition untenable insofar as it appeared to call into question this regulatory function of the League, even though Great Britain had ratified its constituent treaties. A compromise solution was found in 1924: the IAPC agreed to be transformed into a federation of private associations (to which states would no longer be admitted as members), and the League continued its work as an intergovernmental body.

The League's assembly and council decided to entrust this mandate to a new technical body, the CWC. From the outset, it was designed to work in parallel with the Advisory Committee on the Traffic in Women and Children (ACTWC), established in 1922. Just like that committee, the CWC would be an advisory body responsible for advising the League on measures to be taken in that field (ALON, CTFE 243). Both committees were composed of two categories of members: delegates from member states and assessors, who were delegates from private child welfare organizations. This dual representation institutionalized a form of governance in international matters which was similar to the tripartite model introduced by the ILO; thus it gave official blessing to the position of the civil society representatives as permanent technical experts of the League (Marshall 2013).

Its structure did differ in one significant way from that of the ILO: the delegates of states, at least in theory, held more sway over decision-making processes, as they alone had the right to vote. That meant that assessors could not impose on the committee decisions that had not been approved by governments. Still, the assessors played decisive roles: they were closely involved in setting the committee's agenda, leading its discussions, and 
drafting its decisions. Moreover, as the CWC held its sessions only once a year, the assessors became the permanent incarnation of its authority, acting as its official staff, sending out its inquiries, disseminating its decisions and preparing its reports. In short, the assessors were allowed to play a crucial role in the governance of the international child welfare movement. This was a first in the development of international institutional structures: private organizations were henceforth integrated as of right into a body discussing major aspects of contemporary social policy.

\section{Establishment of the CWC: Composition, mandate and margin of manoeuvre}

Once the CWC was established, the League became intimately associated with the cause of children. However, the roadmap for the new committee was not determined precisely. That was its principal difference from the other committees in the Social Section-the ACTWC mentioned above, and another on opium trafficking-whose functions were circumscribed by a clear, and broadly repressive, mandate (Knepper 2011). Nothing like that happened around the CWC; its mandate was not to control a negative phenomenon, but to promote a universal cause, in this case defined in terms of an age group. This configuration was similar to that of the ILO and the International Health Organization (IHO) which were entrusted respectively with protecting workers and the health of populations, and were to draw up international instruments for that purpose. To avoid duplicating the efforts of both these existing agencies, from the outset, the CWC focussed its actions on legal and moral matters (ACTWC Secretariat 1925).

Yet, the CWC had to comply with the League's rules, just like its other advisory committees or technical sections. Thus, it was placed under dual control. First, it had to report on its activities to the Fifth Committee of the Assembly, which dealt with social and humanitarian issues, and which examined its reports, proposing to the assembly that they be approved or amended (Prévost 1936). The Fifth Committee could also order the CWC to include certain items on its agenda. Second, the CWC was also controlled by the League's council itself. It appears that this oversight was largely a formality for all the advisory committees (Ghébali 1972), but for the CWC it was exercised with very special rigour, as I describe below. The CWC also depended on the council when it wished to implement any measure requiring contact with member states, for example, to send out its inquiries to chancelleries. Finally, the CWC was dependent on the staff of the secretary general to implement some of its decisions: conducting inquiries, centralizing correspondence.

The council also appointed the delegates of states to the CWC, after they were proposed by their governments. At its first meeting in 1925, the following countries were represented: Belgium, the British Empire, Denmark, France, Italy, Japan, Romania, Spain, United States and Uruguay; Germany joined in 1926 (ALON, CTWC, p. 273). It would become more universally representative starting in 1934, when delegates from Japan, China and India were appointed (LON 1933, p. 27). The strong presence of the South and North American continents was thus a significant characteristic of the CWC. In particular, the United States, although not a member of the League, sent all the successive heads of its Children's Bureau (Grace Abbott, Katharine Lenroot, Julia Lathrop, and Martha Eliot), to be assessors on the committee. This clearly demonstrated that members of reforming circles in the United States were interested in the League's technical work.

The council also determined which organizations would be nominated as assessors. Not surprisingly, the AIPC and the SCIU were the first two to request and obtain appointments as assessors. This position was highly sought after by international networks, even though, 
unlike government representatives, they had to cover their own travel costs to Geneva. Indeed, by now the League was a much more attractive body as a result of the diplomatic détente that started in 1925: for a number of networks, any position associated with the League became a prerequisite for international recognition and legitimacy. This fact easily explains the steady increase in the number of CWC assessors: 6 assessors in 1925, 12 by 1932. Moreover, the role of assessor provided a decisive influence within the League's bodies, particularly for those benefitting from multiple affiliations. Thus, it was not uncommon for an association to be represented on the CWC not only by its own assessor, but also by a government delegate, who could be a member of the network, and often also a member of the Fifth Committee. Henry Carton de Wiart, Belgium's representative to the League and a founder member of the IAPC, is a good example. A politician and government minister, he was a member of the Belgian delegation to the League from 1928 to 1935 . He sat on the CWC almost without interruption as his own country's delegate, but also as the rapporteur to the Fifth Committee; there, he could support the CWC by responding to any criticisms or questions about it in the Assembly. Other networks benefited from similar support; for example, the international women's organizations were also well represented on the ACTWC (Rodriguez Garcia 2012). The ILO and the IHO, the League's other agencies whose mandate included issues related to youth, were represented on the CWC by liaison officers.

Therefore, the CWC gathered together a diversity of representatives, which enabled it to amalgamate several areas of competence. Its members included well-known persons active in both international and national networks dedicated to child-centred issues, and, more generally, in social or health policy. Among them were Elsa Matz and Gertrud Bäumer for Germany, Eleanor Rathbone for Great Britain, Léon Bernard for France, Stanislas Posner for Poland, Hélène Romniciano for Romania, Ugo Conti for Italy, Estrid Hein for Denmark, and Paulina Luisi for Uruguay. Most of them were familiar with the conventions of democratic debate, in which they participated closely as ministers, deputies or experts. Highly experienced in international fora such as professional and scientific associations, and feminist networks, they shared a common reference framework: parliamentary systems. They therefore brought with them their experience and knowledge of practices that would contribute to the collective expertise and know-how within a body that had no basis for a tradition.

To act on their mandate, the committee members had to establish procedural rules, specify the committee's field of action and develop working methods. This was an unprecedented responsibility: one of them, the Danish Dr. Estrid Hein, later confided that "no member of the Committee was in a position to say exactly how international work such as that entrusted to it should be carried out" (CWC 1929). Despite the tensions that had arisen between their networks immediately after the war, the delegates agreed on the competences of the CWC and its methods of work, stating that it would be a forum for discussing and evaluating child welfare measures in light of national experiences (LON Secretariat 1925). The committee would become a meeting of experts mandated to prepare the decisions of the League's governing bodies by determining policies that they could recommend to member states. By focussing on research and discussion, the CWC therefore took on a profile as an agency that could produce potentially universal standards, along the lines of the action undertaken by the ILO. In a similar way, the CWC could pass non-binding resolutions recommending that states adopt particular good practices. It could also take more direct action by drafting international conventions that members could then submit to their governments for ratification.

For any of these processes to succeed, however, the CWC members had to work by consensus. They needed to agree on the agenda, on the methods to use in surveys (perhaps 
questionnaires or interviews) and on the final wording of their resolutions. Admittedly, their meetings involved spirited debate, but they had to result in compromise, following the prevailing rules in the League. For example, in 1925, Grace Abbott, the delegate from the United States, proposed that the CWC consider a question about sex education for young persons, with a view to promoting its universal dissemination, but delegates from Latin countries, particularly France and Spain, rejected her proposal. They saw it as a form of eugenics that was intrusive and a violation of morals and privacy (CWC 1928, p. 6).

Thus, we see that the CWC's output had to be consensual, since its discussions were devoted to collectively developing standards that experts agreed upon, so they could be used elsewhere. That also explains the CWC's overall reluctance to adopt measures it considered to be too innovative; in contrast, the IHO and the ACTWC were more receptive to the social health concepts promoted by American foundations (Knepper 2011). In this respect, the CWC's action resulted in its mandate being closer to that of the ILO: building up its collective expertise so that it could formulate and disseminate standards appropriate in many nations, in order to promote the cause of the child at the global level.

\section{Beyond rivalries: The development of collective knowledge and expertise (1925 to 1936)}

Before it could spread its ideas widely, the CWC first needed to find ways to exercise this collective expertise. But its margin for manoeuvre was limited by its limited meeting time. The CWC plenary meetings never lasted for more than a week per year, and between those meetings, their only support staff were in the secretariat of the Social Section: in 1929, that was seven persons to serve three committees. In comparison, the ILO had far more resources at its disposal with its cohorts of civil servants, librarians and researchers. Denied such advantages, the CWC members, starting at the first session, turned to the assessors, whom they hoped would perform some of these bureaucratic functions. Therefore, experts from private associations frequently conducted the committee's surveys, gathering data from their national committees, presenting their results and contributing to their assessment in various reports, or drawing up the CWC's draft conventions (Droux 2012b). Thus, it was that during this first stage of international networks becoming institutionalized within the League, assessors took on a wide range of functions, including discussion, research, finding data, and providing expertise. As their sets of skills accumulated, they gained significant power within the agency.

Starting at the first session of the CWC in 1925, the assessor organizations eagerly took on the opportunity offered to them to include on the committee's agenda subjects from their own agendas, such as protecting very young children, determining the age of marriage, assisting foreign children and settling issues around family allowances or delinquent children (ACTWC 1925). In fact, some committee members became quite apprehensive about the impact of such activism. According to the American Julia Lathrop, the committee "had somewhat rashly undertaken a task which was so vast that it would be impossible to carry out" (ALON 1926). And Austen Chamberlain, the British rapporteur to the Council of the League, went even further: in his eyes, the CWC clearly exceeded its competence by addressing issues that only concerned states. Once again we see the constant effort by the British Foreign Office to limit the opportunities for intergovernmental organizations to interfere at the national level (Saunier 2010). During the council session in June 1926, Chamberlain solemnly demanded that the CWC "take care to see that any new subject is strictly within its competence" (LON 1925, p. 865). This criticism was only the first of a 
long series of rebuffs intended to douse the activism of private organizations and limit their influence.

A vital question was at stake here: should international networks be able to impose themselves as partners of sovereign states in their capacity as representatives of international civil society? Some saw these networks as a threat to national sovereignty, if they had the power to place on the CWC agenda the topics about which they, and their associates, had built up their expertise. In fact, Chamberlain had a point: the assessors undoubtedly wanted to reconfigure the governance of child policies. In the first place, they tried to develop standards collectively to define childhood as a function of the capacities and needs of children. They then intended to make use of the status the League accorded to them to exert pressure on states to articulate their legislation and duties (of protection, education and assistance) around this new set of rights of the child that they had just helped to delineate. Despite the tensions and competition that divided them outside of the League, the networks represented on the CWC formed a bloc in defence of this position in response to the council's repeated attempts (especially by British representatives) to limit the committee's action (CWC 1929, p. 57). The statements made by the assessors leave no doubt about the role they wanted to play in relation to states: they wanted to be the "spokesmen of the general public". Indeed, they saw themselves as the only true representatives of an internationalism of action and in action, according to the SCIU delegate, Gertrud Bäumer: "The voluntary associations represented the reality of international organisation which the Governments were still endeavouring to achieve" (CWC 1929, p. 59). Bäumer was a German politician and feminist, and a member of the Reichstag during the Weimar Republic.

In view of their tense relations with the council, at the assembly level the CWC members were frequently supported by the representatives of their countries. For those from countries that were not major powers, this support was particularly important: participation in CWC work became a clear mark of recognition at the international level. This was true for the Canadian and Polish delegates to the Fifth Committee in 1926, who opposed the British demand to limit the competences of the CWC (LON 1926, p. 19). Again, in 1929, the Belgian Carton de Wiart supported the CWC's working methods and activities, as a rapporteur on its activities to the Fifth Committee.

This support allowed the CWC to pursue the route it mapped out at its first session: building a set of social and legal standards relating to child policy, based on a multidisciplinary approach to childhood. It began by clearly outlining certain categories of children that states should hold as a priority as they organized welfare efforts. One example was blind children: at the CWC, representatives from several organizations raised them as a priority. The result was resolutions calling for co-education with sighted children, for the development of appropriate social protection and prevention and for social integration through recreational activities (CWC 1929, 1933). In addition, as it addressed various social issues during its sessions, the CWC acted as a whistle-blower, pointing out specific situations of fragility; it followed up by launching various studies on the age of marriage, delinquent children, guardianship, migrant children and illegitimate children. The objective was not necessarily to determine a model for intervention, but to begin by raising states' awareness about the needs and specific rights of these categories of children: what did they need in terms of assistance, education and legal protection?

The publicity given to these issues apparently had some impact on national legislation, a point that merits more detailed examination. Its impact was hardly negligible, given the statement by the Australian delegate: "The reports of the Child Welfare Committee were studied with great interest by many organisations in Australia. Those concerned with child 
welfare have often endeavoured to put the Committee's recommendations into practice" (LON 1929, p. 12). Admittedly, the CWC cannot take all the credit for disseminating innovative standards or reform policies. For example, its resolution calling on states to stop imprisoning delinquent minors was backed up by other international lobbies, such as the International Penal and Penitentiary Commission. Nevertheless, the role that the CWC played in promoting various reform projects relating to the protection of children's rights deserves attention. For example, consider the issue of granting protection to illegitimate children, and victims of various forms of social stigmatization and legal exclusion (Frost 2013). It was included on the CWC agenda starting in 1926, and several members kept it there until 1936. The inquiries, resolutions and reports focussing on this issue continued to keep it in the news, contributing to the pressure to equalize the status of natural and illegitimate children. As one delegate, Penha Garcia, put it,

There were still too many differences in the various national legislations to make it possible to infer from them any general rules, but the fact of drawing each country's attention to the more liberal measures taken by its sister nations was a first step on the road towards unification. (LON 1929, p. 10)

Just as the ACTWC advocated conventions that would raise the age of both consent and marriage, the standards and resolutions developed through this joint lobbying exerted pressure for modernization, and may well have been instrumental in states amending their existing legislation (Droux 2013b; Tambe 2009). In any case, the CWC's various activities benefited other efforts to promote the cause of children as a category entitled to protection by states, and to define their associated specific needs and rights.

The CWC was also able to exercise influence more indirectly, by pushing other organizations to address these issues. For example, it constantly kept the issues of illegitimate children, blind children and family allowances on its agenda-which contributed to the ILO taking them up. At each session, it called for the ILO to collaborate in carrying out various inquiries that it believed lay within its competence; as a result, the ILO produced a whole series of inquiries and reports the CWC had requested. Accordingly, by taking advantage of the ILO's activism, CWC members pushed it to place a priority on a variety of measures that would affirm the pre-eminence and specific characteristics of children as an important category for action-even though the ILO had not initially seen the subject as very important (Droux 2013a).

Through actions like these, the CWC progressively began to act as a clearinghouse where various issues specific to children were discussed. By placing them on the CWC's agenda, the assessors undoubtedly contributed to data being gathered on their specific characteristics and their degree of urgency; this also encouraged action by other specialized agencies. For example, during the economic crisis in 1929, the CWC included on its agenda such issues as how parental unemployment affected children, and how unemployment affected young workers. By associating both the ILO and the IHO — and its own assessors - with such reflections, the CWC members developed targeted documentation on how health and social protection systems were falling short in protecting children and young persons (CWC 1932). In turn, this work helped bring to the fore a social issue that had thus far attracted only sparse attention and concern from the education, insurance and assistance systems of Western countries: the social integration of young persons (Matasci and Droux 2013).

That also happened when the CWC concerned itself with draft texts of conventions intended to ensure similar social protection for migrant children and young nationals (Droux 2012b). The assessors first raised the subject in the CWC, developed a consensus 
on draft texts for conventions, and then forwarded the drafts to expert bodies in Rome that had more technical capacity to draft them: the International Bureau for the Unification of Penal Law and the International Institute for the Unification of Private Law. Here, certain well-known persons played key roles in ensuring that these issues were taken up; for example, the Belgian H. Carton de Wiart and the Romanians Vespasien Pella and Hélène Romniciano offered the CWC the benefit of their memberships in multiple networks, and opened the way for fruitful inter-network collaboration. Pella was a Romanian jurist, chairman in 1938 of the League's Committee on Legal Questions and a member of several international networks of jurists. Romniciano, who held a doctorate in economics and politics, was a member of the Romanian National Council of Women.

At the same time, the CWC benefitted from its relations with these organizations as it developed its methods of work based on those used by allied or competing agencies. For example its direct questionnaires to states gave way to more targeted inquiries in certain countries, a practice it copied from the IHO (CWC 1930a, 1930b). But it also adopted methods from the ILO: it progressively established specialized sub-committees to manage its agenda, to draft resolutions, and to maintain links with other organizations. And in 1933 France proposed to the Assembly that it provide the CWC with a centre of documentation and information on child welfare that would be responsible for gathering national data, legislation and statistics on the subject, based on another ILO practice (LON 1933). The ILO was undoubtedly the model for a series of organizational proposals the CWC adopted in its effort to become the pre-eminent channel for information in its field of expertise. And it apparently succeeded: given its documentation centre and publications, one member said it represented "a clearing-house, through which countries were able to acquaint themselves with the progress accomplished elsewhere" (LON 1934, p. 21).

What impact did the Committee have on the development of national-level legislation and social policy in the field of child welfare? This still needs to be assessed, even though there are signs that the Committee was able to play a far from negligible role in developing discussion around certain measures at the national level. For example, during the 1930s it helped to broadly disseminate knowledge about various measures to protect young persons, including vocational guidance, work camps, and the extension of compulsory schooling (Matasci and Droux 2013). By making use of the League's regulatory framework and operational mechanisms, CWC members, especially the associations with assessors, appear to have become essential cogs in the convergence of social policy at the global level.

Moreover, because its members adopted a collective and multidisciplinary approach, and focused on a target group they identified in terms of its specific needs and fragility, they were able to reveal the shortcomings of existing social protection systems and develop a consensual procedure to identify the most appropriate measures to remedy them. But they did face strict limits. Although the CWC's focus on children allowed it to build consensus around the need to develop this international expertise, it was impeded in the development of international instruments for action. Accordingly, from the early 1930s, the council ordered the CWC to suspend work in several areas, since the measures it advocated to improve the social welfare of children covered the entire family; this was clearly the case for illegitimate or migrant children within their family (CWC 1930b). In these cases the limitations placed on the CWC's mandate concerning children also restricted its means of action. More than once, the council adamantly refused to extend the CWC's competence to the whole family-which might have enabled its members to address these issues. Moreover, the council continuously tried to obstruct the CWC's activities, particularly by cutting its budget (CWC 1933). Confronted with this opposition, and despite reiterated support from the assembly, the committee often had to turn away from certain fields of 
action and move toward new objectives without being able to complete its work on unresolved issues. Therefore, we can understand why some observers later passed extremely severe judgements on the CWC's action; for example, Julie Eve Vajkai (1937) said it was "burdened by many problems selected in what seemed an utterly haphazard and illogical manner".

In practice, other more lucid witnesses understood another obstacle to international action in the field of child welfare: national sovereignty, as defended by the council, and particularly by Great Britain. In 1930, the SCIU delegate, Wilhelm Polligkeit (1930), made this perceptive assessment:

In future, while paying tribute to [the CWC members'] noble intentions, it will not be possible to prevent ourselves from openly criticising their way of working.... It is clear that the productive work in the CWC could be intensified if the mistrust that the delegates of Great Britain always express with regard to the Committee could be set aside by offering it sufficient opportunities to work.

In the end, the concept of international governance advocated by Great Britain prevailed with the Bruce Report, which initiated an organizational restructuring of the League's technical committees (Ghébali 1972). An Advisory Committee on Social Questions (ACSQ) was established in 1937; it brought together in a single body the CWC and the ACTWC. This merger drowned the cause of children in a series of social issues that the CWC did not have the time to examine in depth before it disappeared in 1939. In fact the restructuring had a deeper impact on the governing mechanisms because it abolished the permanent positions assessors had previously held; now they were merely corresponding members, with temporary membership. Therefore, states reclaimed their control of the committee, since only their delegates would be permanent members of the ACSQ (ACSQ 1937, pp. 155 ff; LON 1937), a configuration which directly inspired the United Nations Economic and Social Council. Private organizations represented at the United Nations would never regain the power they had exercised during their time at the $\mathrm{CWC}$; in the 1970s, this led them to look for positions as outsiders where they could make their voices heard. Perceptive observers, such as the ILO delegate to the CWC, pointed out how the international networks were marginalized, and how that reduced the impact of civil society in intergovernmental organizations:

I may say that I think this was, from the point of view of the League, a very great mistake. The vitality of the Committee had in fact been due to the presence of the assessors, and its real work was to act as coordinating agency for the various voluntary associations. (Johnston 1937)

This speaker rightly emphasized the fundamental role that a diverse range of private networks had come to play in the League of Nations through their function of relaying both to public opinion and to individual countries the work and spirit of the League, to which they themselves had contributed through their action as advocacy networks.

\section{Conclusions}

A wealth of lessons emerge from this analysis of the mechanisms for collaboration used by non-governmental networks and associations within the international organizations that emerged from the Treaty of Versailles. First, we now have historical context for the role these groups played as platforms for collaboration with networks, movements and 
associations emerging from civil society, emphasizing the characteristics of the period. We also see the density of the exchanges between transnational reform networks, and their capacity to produce new categories of analysis, new models of intervention and new international instruments. Furthermore, Saunier's (2008) analysis, from a relational perspective, of the interaction between international agencies or organizations shows the tactics that certain agencies, such as the ILO, used to take over a whole series of international networks and agencies and to take action to disseminate their standards. This analysis helps us understand that the ILO's standard-setting action, in the form of having conventions adopted, was only one of the approaches international actors could use to create the conditions for convergence between national social policies. The CWC's strategy was focused less on producing standards, and more on reaffirming that a specific age group — children — was entitled to national solidarity; more specifically it aimed to define the needs, characteristics and rights of that age group.

Nevertheless, further analysis remains to be done, particularly by studying the downstream transformations of such agencies, both governmental and non-governmental, with the advent of the United Nations system. In parallel, the interplay of networks and movements, at the crossroads between global international fora and regional bodies (such as the European Communities) needs to be studied in greater depth. And more work is needed to finish analyzing the processes through which various organizations appropriated spheres of influence at the national and local levels, including cases of rejection or resistance. In particular, what role was played by local bodies affiliated to international networks? In this regard, attention should be paid not only to the role of these associations, but also to that of certain individuals who turned out to be veritable missionaries of internationalism, such as the Belgian Henry Carton de Wiart. These individuals shed light on the complex nature of the relations between the various levels, and the essential role played by certain individuals and associations in disseminating ideas, projects, and measures, thus overcoming or subsuming the deep rivalries which separated and divided networks and movements.

\section{References}

ACSQ [Advisory Committee on Social Questions] (1937). Draft report of the ACSQ, 1st session, AprilMay. ALON: ACSQ.

ACTWC [Advisory Committee on the Traffic in Women and Children] (1925). Draft minutes of ACTWC fourth session, 20-27 May. ALON, ACTWC 273.

ACTWC Secretariat (1925). Report submitted to the fourth ACTWC session. ALON, ACTWC 229.

AEG, ASCIU [Archives of the State of Geneva, Archives of the Save the Children International Union] (1923). Minutes of the fourth General Council, 22-23 February 1923. AP92.3.29.

ALON [Archives of the League of Nations] (1926). Minutes. ASDN, C 264 M 103. 1926. IV: CPE/2 ${ }^{\mathrm{e}}$ session, $\mathrm{PV}$.

Birn, A.-E. (2007). Child health in Latin America: Historiographic perspectives and challenges. História, Ciências, Saúde-Manguinhos, 14(3). doi:10.1590/S0104-59702007000300002.

Boli, J., \& Thomas, G. M. (Eds.) (1999). Constructing world culture: International non governmental organizations since 1875. Stanford: Stanford University Press.

Conrad, S., \& Sachsenmaier, D. (Eds.) (2012). Competing visions of world order: Global moments and movements, 1880s-1930s. Basingstoke: Palgrave-Macmillan.

Cooter, R. (Ed.) (1992). In the name of the child: Health and welfare, 1880-1940. London, New York: Routledge.

CWC [Child Welfare Committee] (1928). Report on the work of the fourth session. ALON, C 195 M 63. 1928. IV.

CWC (1929). Minutes of the fifth session. ALON, C 295 M 98. 1929. IV. 
CWC (1930a). Minutes of the sixth session. ALON, C 137 M 137.1930. IV.

CWC (1930b). Report on the work of the sixth session. ALON, C 137 M 137.1930. IV.

CWC (1932). Report on the work of the eighth session. ALON.

CWC (1933). Report on the work of the ninth session. ALON, C 295 M 98. 1929. IV.

Droux, J. (2011). L'internationalisation de la protection de l'enfance: Acteurs, concurrences et projets transnationaux (1900-1925) [The internationalization of child welfare: Transnational actors, rivalries and projects (1900-1925)]. Critique Internationale, 52, 17-33.

Droux, J. (2012a). La tectonique des causes humanitaires: Concurrences et collaborations autour du Comité de protection de l'enfance de la Société des Nations (1880-1940) [The tectonic structure of humanitarian causes: Rivalries and collaboration around the League of Nations Child Welfare Committee]. Relations Internationales, 151, 77-90.

Droux, J. (2012b). Les projets de conventions sur l'assistance aux mineurs étrangers (1890-1939): Enjeux et impasses de l'internationalisation des politiques sociales (1890-1939) [Projects for treaties on the welfare of foreign minors (1890-1939): Issues and dead ends in the internationalization of social policy]. Revue d'histoire de la protection sociale, 5, 15-29.

Droux, J. (2013a). From inter-agency concurrences to transnational collaborations: The ILO contribution to child welfare issues during the interwar years. In S. Kott \& J. Droux (Eds.), Globalizing social rights: The International Labour Organization and beyond (pp. 262-279). Basingstoke: Palgrave MacMillan.

Droux, J. (2013b). Une contagion programmée: La circulation internationale du modèle des tribunaux pour mineurs dans l'espace transatlantique (1900-1940) [Planned contagion: The international dissemination of the model of juvenile courts in the transatlantic area]. In M. Kaluszynski \& R. Payre (Eds.), Les sciences du gouvernement: Circulation(s), traduction(s), réception(s) (pp. 102-117). Paris: Economica.

Dupont-Bouchat, M.-S., \& Pierre, E. (2001). Enfants et justice au XIX siècle: Essai d'histoire comparée de la protection de l'enfance 1820-1914, France, Belgique, Pays-Bas, Canada [Children and the justice system in the $19^{\text {th }}$ century: Comparative historical essay on child welfare 1820-1914; France, Belgium, Netherlands, Canada]. Paris: PUF.H

Fisher, S. (2011). Boys and girls in no man's land: English-Canadian children and the First World War. Toronto: Toronto University Press.

Frost, G. (2013). When is a parent not a parent? Custody and illegitimacy in England, 1860-1930. Journal of the History of Childhood and Youth, 6(2), 236-262.

Fuchs, E. (2007). The creation of new international networks in education: The League of Nations and educational organizations in the 1920s. Paedagogica Historica, 43(2), 199-209.

Ghébali, V.-Y. (1972). Aux origines de l'ECOSOC: L'évolution des commissions et organisations techniques de la SDN [The origins of ECOSOC: The development of the League of Nations technical committees and organizations]. Annuaire français de droit international, 18, 469-511.

Gorman, D. (2012). The emergence of international society in the 1920s. New York: Cambridge University Press.

Gregarek, R. (1995). Le mirage de l'Europe sociale: Associations internationales de politique sociale au tournant du 20e siècle [The mirage of social Europe: International social policy associations at the beginning of the 20th century]. Vingtième siècle, 48, 103-118.

Hofstetter, R. (2012). La transformation de l'enfant en écolier (du $19^{\mathrm{e}}$ au milieu du $20^{\mathrm{e}}$ siècle): Les "eurêkas" des sciences de l'homme naissantes, entre scientisme et romantisme: Un "naturalisme" de l'enfance [The transformation of children into schoolchildren (from the $19^{\text {th }}$ century to the middle $20^{\text {th }}$ century): The breakthroughs of emerging human sciences, between 'scientism' and romanticism: A 'naturalism' for childhood"]. Paedagogica Historica, 48(1), 31-50.

Hofstetter, R., \& Schneuwly, B. (2013). The International Bureau of Education (1925-1968): A platform for designing a "chart of world aspirations for education". European Educational Research Journal, 12(2), 215-230.

Iriye, A., \& Saunier, P.-Y. (Eds.) (2009). Palgrave dictionary of transnational history. Basingstoke: Palgrave-Macmillan.

Johnston, G. A. (1937). Note to Tixier, 13 May. In ILO archives L 10/5/1: ACSQ: Sessions and reports of the liaison officer.

Keck, M. E., \& Sikkink, K. (1998). Activists beyond borders: Advocacy networks in international politics. Ithaca, NY: Cornell University Press.

Knepper, P. (2011). International crime in the 20th century: The League of Nations era, 1919-1939. Basingstoke: Palgrave Macmillan.

Kott, S. (2008). Une 'communauté épistémique' du social? Experts de l'OIT et internationalisation des politiques sociales dans l'entre-deux-guerres [An 'epistemic community' on social issues? ILO experts and the internationalization of social policy between the wars]. Genèses, 71. 
Kott, S., \& Droux, J. (Eds.) (2013). Globalizing social rights: The International Labour Organization and beyond. Basingstoke: Palgrave-Macmillan.

Laqua, D. (Ed.) (2011). Internationalism reconsidered: Transnational ideas and movements between the world wars. London: Tauris.

LON [League of Nations] (1921). Official journal, minutes of the thirteenth session of the council. Geneva: LON.

LON (1924). Official journal, records of the fifth assembly, plenary meetings. Geneva: LON.

LON (1925). Official journal, minutes of the fortieth session of the council. Geneva: LON.

LON (1926). Official journal, records of the seventh ordinary session of the assembly, meetings of the committees, minutes of the fifth committee. Geneva: LON.

LON (1929). Official journal, records of the tenth ordinary session of the assembly, meetings of the committees, minutes of the fifth committee. Geneva: LON.

LON (1933). Official journal, records of the fourteenth ordinary session of the assembly, meetings of the committees, minutes of the fifth committee. Geneva: LON.

LON (1934). Official journal, records of the fifteenth ordinary session of the assembly, meetings of the committees, minutes of the fifth committee. Geneva: LON.

LON (1937). Report on the work of the league, 1936-37. ALON A.6.1937.

LON Secretariat (1925). Memorandum on the programme of activities of the CWC, 16 May. ALON, CWC 1.

Marshall, D. (1999). The construction of children as an object of international relations: The Declaration of Children's Rights and the Child Welfare Committee of the League of Nations, 1900-1924. The International Journal of Children's Rights, 7, 103-147.

Marshall, D. (2009). The causes, promises and problems of coordinated actions in favor of children in war and peace: Philanthropists, experts and the League of Nations, 1914-1930. Paper presented at the Workshop on Transnational Networks of Experts and Organizations, Geneva, 31 August-1 September 2009.

Marshall, D. (2013). Children's rights from below: Canadian and transnational actions, beliefs, and discourses, 1900-1989. In D. Goutor \& S. Heathorn (Eds.), Taking liberties: A history of human rights in Canada (pp. 189-212). Oxford: Oxford University Press.

Matasci, D., \& Droux, J. (2013). Les jeunes en jeu: Circulations internationales de dispositifs et de politiques d'encadrement de la jeunesse (1929-1939) [The cause of children: International dissemination of youth measures and policies (1929-1939)]. Traverse, 20(2), 75-91.

Pedersen, S. (2007). Back to the League of Nations. American Historical Review, 112(4), 1091-1117.

Pignot, M. (2012). Allons enfants de la patrie: Génération Grande Guerre [Onward, the nation's children: The Great War generation]. Paris: Editions du Seuil.

Polligkeit, W. (1930). Letter. AEG, SCIU archives, AP92.10.33.

Prévost, M.-H. (1936). Les commissions de l'Assemblée de la Société des Nations [The committees of the Assembly of the League of Nations]. Paris: A. Pedone.

Rodriguez Garcia, M. (2012). The League of Nations and the moral recruitment of women. International Review of Social History, 57, 97-128.

Rollet, C. (2001). La santé et la protection de l'enfant vues à travers les congrès internationaux (1880-1920) [Child health and welfare seen through international meetings (1880-1920)]. Annales de démographie historique, 97-116.

Saunier, P.-Y. (2008). Les régimes circulatoires du domaine social, 1800-1940: Projets et ingénierie de la convergence et de la divergence [Dissemination networks in the social field, 1800-1940: Projects and engineering for convergence and divergence]. Genèses, 71, 4-25.

Saunier, P.-Y. (2010). Borderline work: ILO explorations onto the housing scene until 1940. In J. Van Daele, M. Rodriguez García, G. Van Goethem, \& M. van der Linden (Eds.), ILO histories: Essays on the International Labour Organization and its impact on the world during the twentieth century (pp. 197-221). Bern: Peter Lang.

Tambe, A. (2009). The state as surrogate parent: Legislating nonmarital sex in colonial India, 1911-1929. Journal of the History of Childhood and Youth, 2(3), 393-427.

Vajkai, J. (1937). Intervention of J. Vajkai (SCIU). ILO archives, L 10/5/1: Advisory Committee on Social Questions, 1st session.

Joëlle Droux (Switzerland) is a senior lecturer at the University of Geneva, Faculty of Psychology and Education, and co-leader of ERHISE (Social History of Education Research Group). She studies the history of international child welfare movements and the contemporary evolution of social and humanitarian networks from a transnational perspective. She also develops research projects on the long-term evolution of Swiss policies for child and youth welfare. 